\title{
Post-Occupancy Evaluation of Information Signs and Pre-Boarding Behavior in a Historic Railroad Station
}

\author{
Meng-Cong Zheng*1, Ming-Shih Chen ${ }^{2}$ and Pei-Ying $\mathrm{Li}^{3}$ \\ ${ }^{1}$ Assistant Professor, Department of Wood Science and Design, National Pingtung University of Science and Technology, Taiwan \\ ${ }^{2}$ Associate Professor, Institute of Industrial Design, Tunghai University, Taiwan \\ ${ }^{3}$ Ph.D. Student, Design Psychology Unit, Department of Design Science, Chiba University, Japan
}

\begin{abstract}
This survey was conducted at Tainan station which is an At-Ground Station. The designation of the Tainan station as a historic site limits, certain changes to the structure such as re-constructed or extended. This study examined passenger behavior in this historic station and how management can design and locate effective information signs with limited operational funds. The three parts of the study were observation, post occupancy evaluation (POE), and interviews and questionnaires. The survey indicated that experienced travelers tend to enter the train station directly, read the A4 information sign to understand the train schedule, buy ticket at ticket vending machine, and then go directly to the platform. The survey results indicated that information signs close to ticket window (A1) should be replaced by information sign A4 which provides immediate information on schedules. This supports experienced travelers, who use information sign A4 most often. Management teams can use good graphic designs on walls and corridors as well as pavements and restrict advertisements to limited locations. Staff should provide temporary support or set up temporary, moveable information signs to guide train passengers. In the future, studies of train stations should investigate information signs to connect the traffic vehicles of its surroundings, and review further improvement for information signs of the station.
\end{abstract}

Keywords: post occupancy evaluation; information signs; historic railroad station

\section{Introduction}

The survey "Taiwan Railways Administration" indicated that the notice of waiting time and delay time is one of the strongest needs of travelers. During peak hours, and especially on holidays, the train station can become extremely crowded. Information signs could not be found immediately. Even if the signs can be found, travelers may not have time to read the detailed contents. Both of these factors also affect the smooth flow of traffic. Taiwan train stations are currently classified by three spatial characteristics - Elevated Station, At-Ground Station and Underground Station. This survey examined a Tainan At-Ground Station, with three platforms. The number of scheduled train runs here is the $3^{\text {rd }}$ largest in Taiwan, which is slightly less than that of Taipei and Kao Hsiung stations. The current station structure was finished on March 15, 1936 and was designated as historic place in 1998. The

*Contact Author: Meng-Cong Zheng, Assistant Professor,

National Pingtung University of Science and Technology,

1, Shuefu Road, Neipu, Pingtung 912, Taiwan

Tel: +886-8-7703202 \#7131 Fax: +886-8-7740165

E-mail: zmcdesign@hotmail.com

(Received April 8, 2009 ; accepted January 20, 2010) station has three major areas. The front section is the lobby with ticket windows, the middle section is the waiting area near the platforms, and the back section is the platforms. In front of the front section, is a corridor for passengers who arrive by car or motorcycle and the two sides are for passengers who arrive on foot.

At-Ground Station is the most common type in Taiwan. Since the Tainan station has been designated a historic site, changes to the structure are limited. For example, the building cannot be re-constructed or extended. Station management can only add movable information signs to give instructions to travelers, and maintain the current information signs. As the number of passengers began to decrease in recent years, the train station management team began to rent the bulletin board spaces to businesses for advertisements to earn some income. However, information signs and advertisements may confuse passengers. Station management must carefully consider the position and quantity of advertisements. (Tanaka, 2005)

This study analyzed the interaction between people and environment, such as boarding behavior and then conducted POE (post occupancy evaluation). The study attempts to clarify how travelers use this historic station and how management can design and locate the 
Table 1. Classifications of Present Signs

\begin{tabular}{|c|c|c|c|c|c|c|c|c|c||}
\hline \multicolumn{2}{|c|}{ Presentation } & \multicolumn{4}{c|}{ Content } & \multicolumn{3}{c|}{ Installation } \\
\hline $\begin{array}{c}\text { Fixed } \\
\text { printing }\end{array}$ & Temporary poster & identification & direction & orientation & location & regulation & $\begin{array}{c}\text { Upper } \\
\text { hanging }\end{array}$ & standing & hanging \\
\hline$\square$ & $\triangle$ & A & B & C & D & E & a & b & $\mathrm{c}$ \\
\hline
\end{tabular}

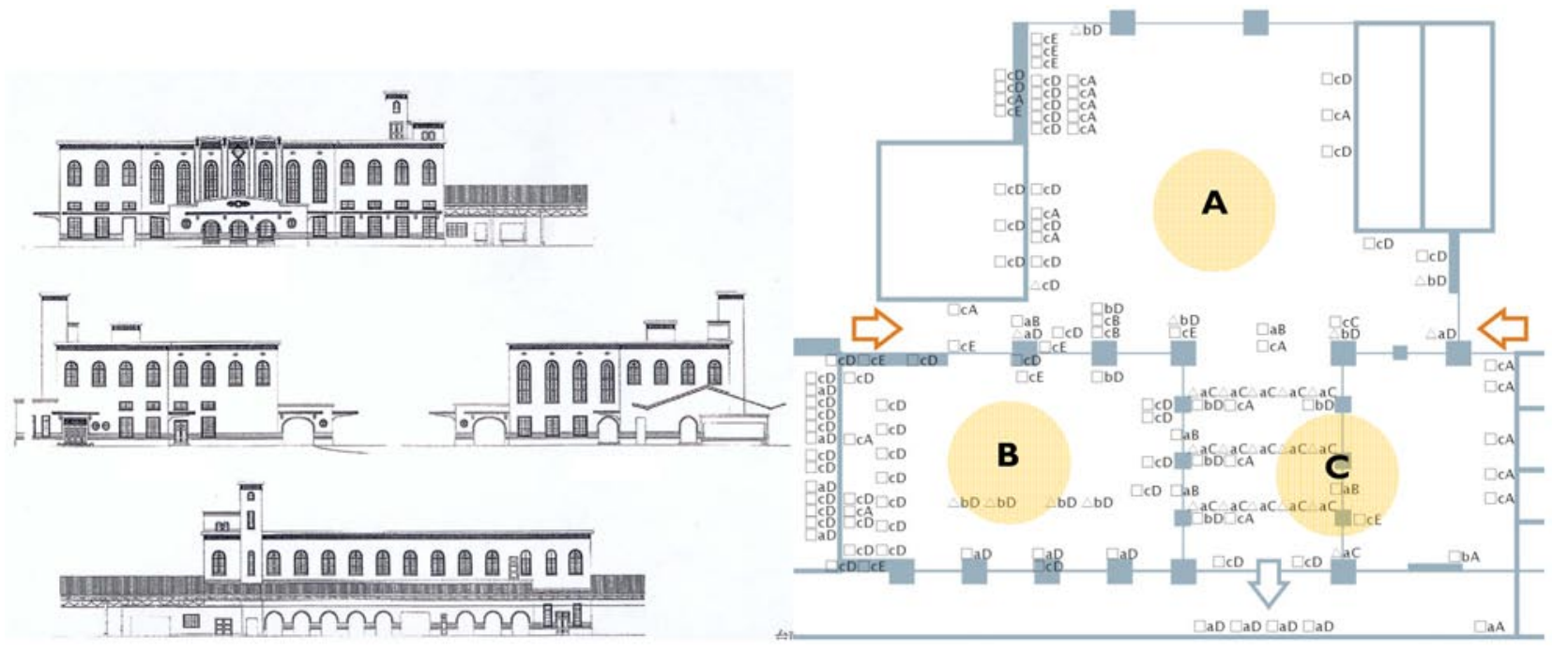

Fig.1. Location of Information Signs at Tainan Station by Type of Sign, Content and Type of Installation

information signs effectively with limited operational funds.

\section{Current Status of Information Signs at Tainan Train Station}

When the Tainan station was established in 1936, its structure was solid. Importantly, it is marked as historic place, which precludes major structural changes.

There are four areas in the front section. Two areas are ticket windows; another is a waiting area with seats; the 4-forth is the corridor. To study how information signs are used, one usually records the location and the quantity of information signs in order to observe how they are used. (Lee Miar, 2005). Signs are classified as temporary poster or printing. Installed signs are classified as upper hanging, standing, or hanging (Table 1.). As Fig.1. shows, in the area A where vending machines are located and area B where ticket windows are located, hanging type signs are used to provide train schedules information. In area $\mathrm{C}$, the signs are unrelated to the train schedule and are mostly advertisements. The information signs at Tainan station are mostly ceiling hanging type and wall hanging type. Free standing types are rarely used because they occupy floor space. Most information signs are related to train schedules. However, travelers are easily confused due to excessive signage unrelated to train schedules, such as advertisement posters. (Fig.1.)

\section{Study Method}

After understanding the current situation of information signs, this study analyzed the behavior of Tainan train station users, in order to understand the relationship between user behavior and information signs.

This study was performed in three parts: observation followed by interviews and questionnaires in the post occupancy evaluation (POE).

a. Observation

The study analyzed three public entrances during weekdays and holidays (including weekends). The interviewers followed only one person each time to record his/her route, information signs that they read, their ticket purchasing process, and movements until they entered the platform gate. First, subjects were chosen from the left entrance and then follow, to record their behavior until they reached the gate. Again, choose one person from central entrance, and do the same thing. One person was then selected from the right entrance, and the process was repeated. One hundred persons were selected in this manner. Half the subjects were selected at the left entrance, a third were selected in the center and one-sixth were selected at the right entrance.

b. Interviews

To prepare a questionnaire for this study, twelve sample passengers were selected for detailed interviews. They were offered free tickets and asked about their destinations; their behaviors were recorded from entering the train station to reaching platform gate. The recorded entries included what information they used, how they buy tickets, how they confirm train schedule, circulation inside the station, waiting time, and waiting area. They were then interviewed to determine the reasons for their specific choices. c. Questionnaire Design 
Based on the information obtained in steps a and $\mathrm{b}$, a questionnaire was designed for distribution to a sample of two hundred persons. A major concern was that many in their travel rush would not cooperate and would ignore interview requests.

\section{Results}

The survey showed that more than half the passengers preferred the left entrance to go in or out of the station (Fig.2.). Outside and to the left was a sidewalk prepassengers used the train station on holidays than on weekdays.

The information sign most used was A4, which is located in front of platform gate (Fig.3.). The second most used sign is A1, which is placed over the ticket windows (Fig.4.). A1 shows the train schedule. The A4 shows the trains schedule for the last four just over entering gate.

The other information signs next to Ticket vending machines were not be classified for this survey since travelers buy tickets and read information at the same time. The people who come through central entrance, usually purchase tickets from ticket windows (Fig.5.). These passengers often have luggage and prefer to buy tickets from the ticket window rather than from the ticket machines (Fig.6.). Thirty eight percent of

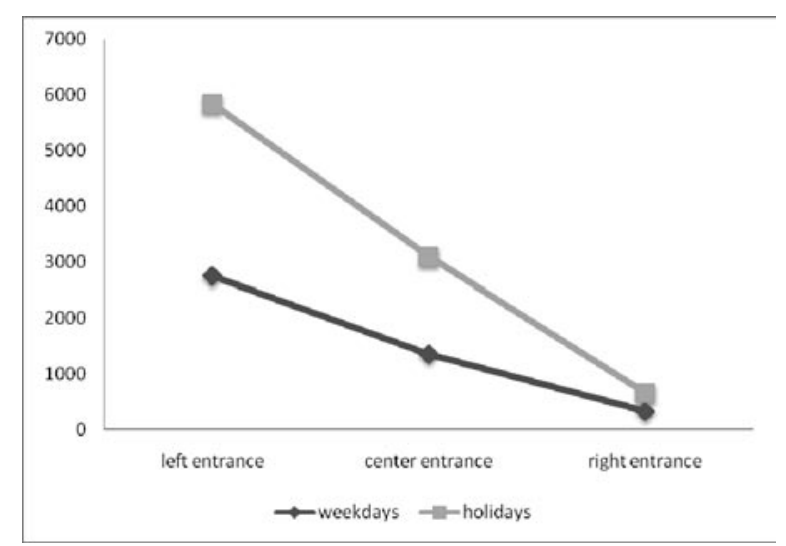

Fig.2. Number of Passengers by Left, Center and Right Entrances at Tainan Train Station

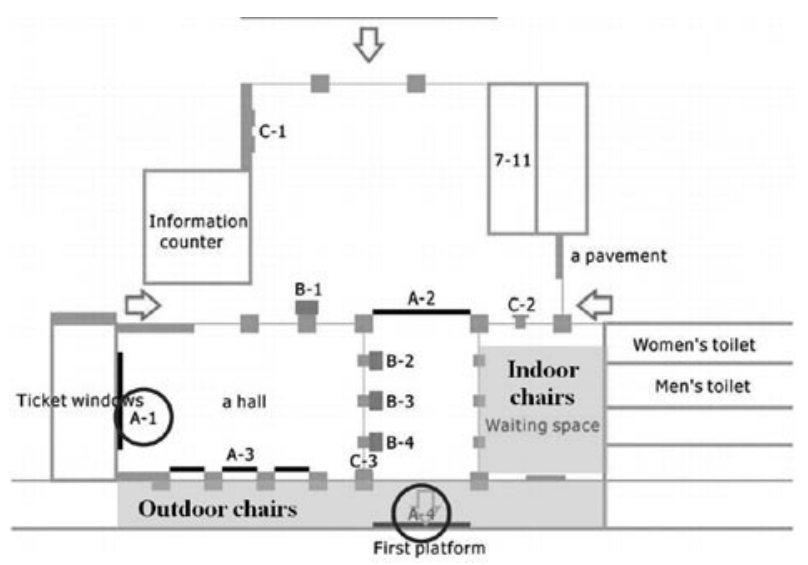

Fig.3. Floor Plan of Entrances, Major Signs and Areas at Tainan Train Station

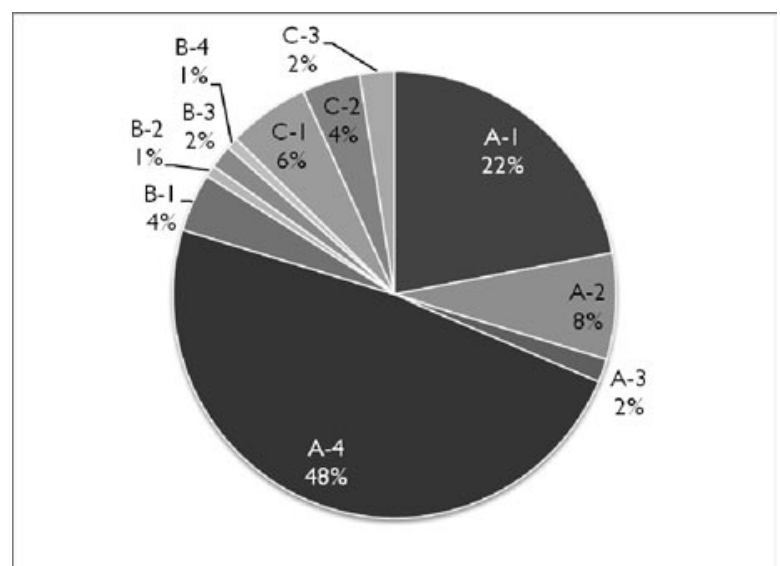

Fig.4. Share of Sample Sign Viewers by Information Board

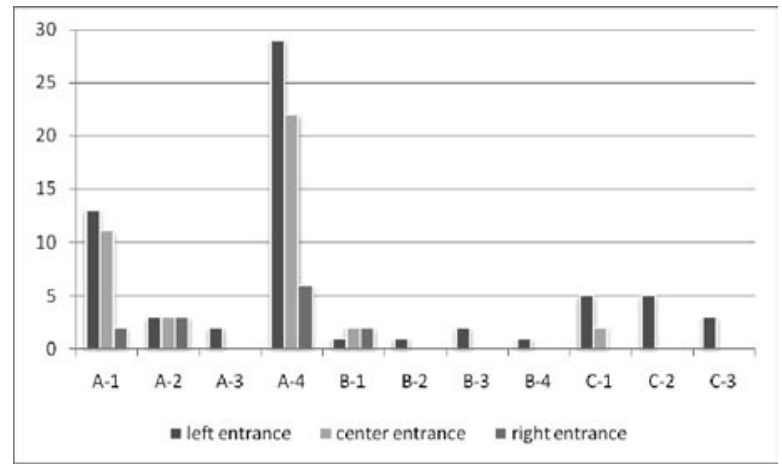

Fig.5. Frequency of Information Signs Used by Entrance Used

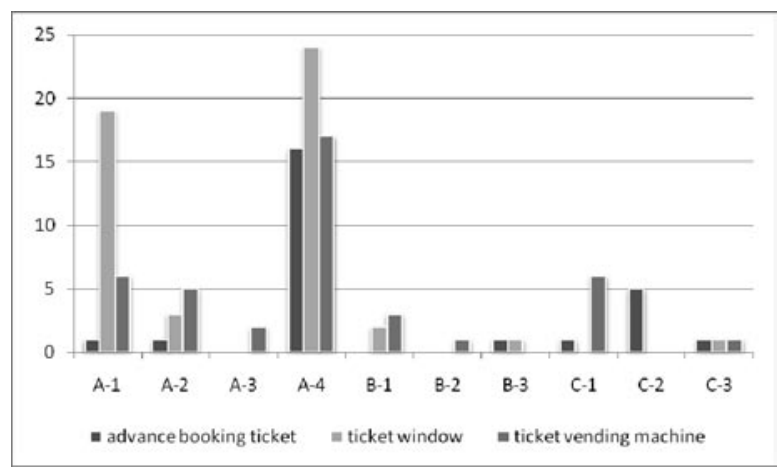

Fig.6. Ticket Buying Preferences and Use of Information Signs

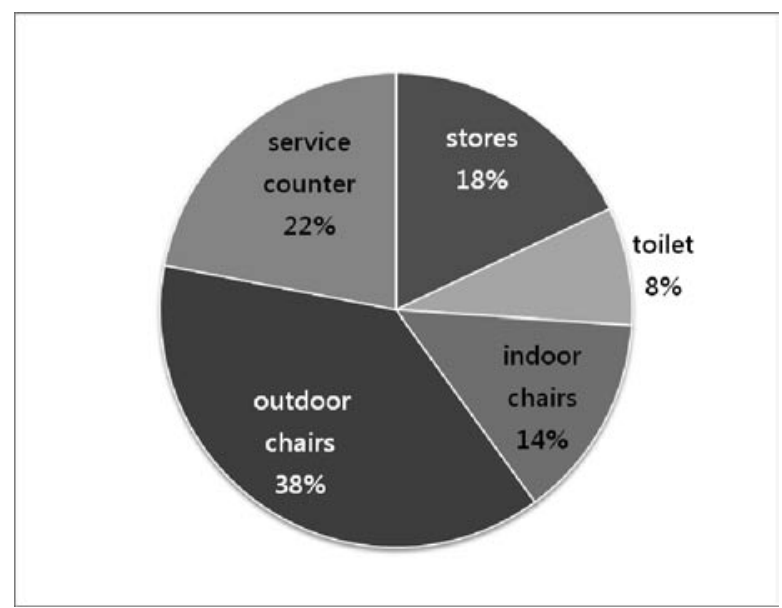

Fig.7. Preference for Waiting Areas by Passengers 
Table 2. First-Time Station Users Experience of Information Signs in Tainan Train Station

\begin{tabular}{|c|c|c|c|c|c|c|c|c|c|c|c|c|c|}
\hline \multicolumn{2}{|l|}{ Interview subjects } & $\triangle$ & $\triangle$ & $\triangle$ & $\mathrm{O}$ & $\mathrm{O}$ & $\mathrm{O}$ & $\square$ & $\square$ & $\square$ & $\square$ & $\square$ & $\square$ \\
\hline \multicolumn{14}{|l|}{ Sign used } \\
\hline \multirow{2}{*}{ Upper hanging } & $\mathrm{A}-1$ & $\Delta$ & $\mathbf{\Delta}$ & $\Delta$ & 9 & & & $\mathbf{\square}$ & & & & & \\
\hline & A-4 & $\Delta$ & & & 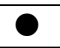 & 0 & 0 & & $\square$ & $\mathbf{\square}$ & $\square$ & & \\
\hline Hanging & $\mathrm{C}-1$ & & & & & 0 & 0 & & & $\square$ & $\square$ & $\square$ & \\
\hline \multicolumn{14}{|l|}{ Sign selection } \\
\hline \multirow{2}{*}{ Reason for choosing } & Appropriate location & & $\mathbf{\Delta}$ & & 0 & & & $\square$ & $\square$ & $\square$ & $\square$ & & 口 \\
\hline & Content is clear & $\Delta$ & & & & 0 & 0 & $\square$ & $\square$ & & & & \\
\hline \multirow{2}{*}{$\begin{array}{l}\text { Reason for not } \\
\text { choosing }\end{array}$} & Not notice & & $\Delta$ & & & 0 & & $\mathbf{\square}$ & & $\mathbf{\square}$ & & & \\
\hline & Unnecessary information & $\Delta$ & & & & & 0 & & $\mathbf{a}$ & $\mathbf{a}$ & & & \\
\hline \multirow{2}{*}{ Other information } & Time broadcast & $\Delta$ & & $\Delta$ & & 0 & & & $\square$ & $\mathbf{a}$ & $\mathbf{a}$ & $\mathbf{\square}$ & \\
\hline & Hanging information & & $\Delta$ & & & & 0 & 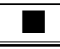 & & & $\square$ & & $\square$ \\
\hline \multicolumn{14}{|c|}{ Preferred method of purchasing tickets and reason for choosing that method } \\
\hline \multirow{2}{*}{$\begin{array}{l}\text { Ticket vending } \\
\text { equipment }\end{array}$} & Convenient & & & & & ○ & ○ & $\mathbf{\square}$ & & $\mathbf{\square}$ & & $\square$ & 口 \\
\hline & Save time & & & & ○ & & $\mathbf{0}$ & $\mathbf{\square}$ & $\mathbf{\square}$ & & & $\mathbf{\square}$ & $\square$ \\
\hline \multirow[t]{2}{*}{ Ticket window } & $\begin{array}{l}\text { Do not know how to use ticket } \\
\text { vending machine }\end{array}$ & $\boldsymbol{\Delta}$ & $\mathbf{\Delta}$ & & & & & & & & & & \\
\hline & Question directly & $\Delta$ & & $\Delta$ & ○ & O & & & & & & & \\
\hline \multirow{3}{*}{ Other information } & Tickets price & & & $\Delta$ & ? & & 0 & $\mathbf{\square}$ & $\mathbf{a}$ & $\mathbf{a}$ & & $\square$ & \\
\hline & Explanations of purchasing & $\Delta$ & & $\Delta$ & ○ & & & & & & & & \\
\hline & Available service & & $\Delta$ & & & 0 & & & & & $\mathbf{a}$ & & \\
\hline \multicolumn{14}{|c|}{ Confirmation of train schedule } \\
\hline \multirow{5}{*}{ Method of confirming } & Broadcast voice & $\Delta$ & $\mathbf{\Delta}$ & $\Delta$ & & 0 & & & & & & & \\
\hline & Signboard located on the platform & $\Delta$ & & $\Delta$ & & 0 & & & $\square$ & $\mathbf{a}$ & $\square$ & & 口 \\
\hline & From purchasing & $\Delta$ & & & & & 0 & & & $\mathbf{a}$ & $\mathbf{a}$ & $\mathbf{a}$ & \\
\hline & Without confirming & & & $\Delta$ & 0 & & & $\mathbf{a}$ & & & & & $\mathbf{\square}$ \\
\hline & Question directly & & & $\Delta$ & & ○ & & $\mathbf{\square}$ & $\mathbf{\square}$ & & & $\square$ & \\
\hline \multirow{2}{*}{ Condition } & Missing trains & & & & & & & $\mathbf{\square}$ & & & $\mathbf{\square}$ & $\mathbf{\square}$ & $\square$ \\
\hline & Forget the number of platform & $\Delta$ & $\Delta$ & $\Delta$ & O & 0 & & & $\square$ & $\square$ & & $\square$ & \\
\hline \multicolumn{14}{|l|}{ General Comments } \\
\hline \multirow{7}{*}{ Evaluations of sign } & Difficult to read & $\Delta$ & & $\Delta$ & & & & & & $\square$ & $\square$ & & $\square$ \\
\hline & Excessive information & & $\Delta$ & & 0 & & & & & & $\square$ & & \\
\hline & Easy to read & $\Delta$ & & & & 0 & & $\mathbf{\square}$ & $\mathbf{\square}$ & & $\mathbf{\square}$ & $\mathbf{\square}$ & \\
\hline & The amount is suitable & & & & & 0 & 0 & $\square$ & $\square$ & & & & \\
\hline & \begin{tabular}{|l} 
Time consuming \\
\end{tabular} & & $\Delta$ & & & & 0 & & & & & $\mathbf{\square}$ & \\
\hline & Nervous and hurried & $\Delta$ & & $\Delta$ & & 0 & & $\square$ & & & $\mathbf{\square}$ & $\mathbf{\square}$ & \\
\hline & Unhurried and easy & & & & O & & & $\overline{1}$ & $\square$ & $\overline{1}$ & & & \\
\hline \multirow{3}{*}{$\begin{array}{l}\text { Suggested } \\
\text { improvements }\end{array}$} & Information provision & & & & & & & $\square$ & & & $\mathbf{a}$ & $\square$ & $\mathbf{\square}$ \\
\hline & Hasten purchasing & & & & 0 & 0 & 0 & $\mathbf{\square}$ & & $\mathbf{\square}$ & & $\mathbf{\square}$ & \\
\hline & Neat environment & $\Delta$ & $\Delta$ & $\Delta$ & & & & $\square$ & $\mathbf{\square}$ & $\mathbf{\square}$ & & $\mathbf{\square}$ & $\square$ \\
\hline \multirow{2}{*}{ Service counter } & Question directly & $\Delta$ & $\Delta$ & $\Delta$ & & 0 & & $\mathbf{a}$ & & & & $\mathbf{a}$ & \\
\hline & Exchange money & & & & ○ & & & $\square$ & $\mathbf{\square}$ & $\mathbf{\square}$ & & & \\
\hline
\end{tabular}

observed objects, the largest share in the survey, waited in the area with chairs in front of gates (Fig.7.). Over half the seats in the station were also located in this area. The distance between this area and information sign A4, leading to platforms was also the shortest. Passengers who buy tickets at ticket windows, usually read the train infomation on the information signs A1, which are located over the ticket windows and show train schedules. No matter how people buy tickets, they also pay attention to information sign A4, which is over the platform gate.

After purchasing tickets but before entering the gate to the platforms, passengers were observed as they moved around in the train station. Some were looking for seats to get rest, and some were looking at the information signs A4. Even on weekdays when traffic was less than on holidays, people moved back and forth in various areas of the station, which increased the difficulty of getting to trains. Space would be used effectively if information signs and other functions were placed in convenient locations.

\section{Post Occupancy Evaluation Interview:}

Twelve passengers were selected to help design the questionnaire for the principal survey. All were 
first time users of the Tainan train station. Three were seniors, three were handicapped, and six were general public. In this study, the survey staff asked these firsttime users for their destination, offered to pay for their tickets as part of the program, but asked them to buy tickets themselves. The interviewer then asked survey questions before interviewees went into the platform gate. Fig.9. shows their responses to questions regarding information signs being used, reason for reading that sign, method of buying ticket, how they confirm the train schedule and "general opinions" about their experience.

The interview process revealed that information signs A1, A4 and C1 were read most frequently by the interviewees. The reasons were the content and location. Interviewees also agreed that using ticket vending machines was faster than buying tickets at the ticket window. Interviewees listened to the train broadcast, read information on A4, or asked at the ticket window to confirm the train schedule. Most interviewees were unsure of which platform to taken. Seniors preferred radio and question directly. These two ways seem to be easier then searching for information visually. Handicapped travelers were concerned about speed of buying ticket because line up for buying ticket is not easy for them. Users who indicate that signs were hard to read are almost selecting sign because of its location. However, users who evaluate sign amount is suitable selecting sign because of its clear content. Travelers had no difficulty finding signs related to boarding, but they were concerned about whether or not the content of sign was clear. Users evaluate signs in order of its location, next is its content, which is understandable since users must first find the sign they want and then start to read and understand the content of sign (Table 2.).

The amount of information also confused them. The noisy station environment made people nervous and uncomfortable while waiting for their trains.

Based on responses from these interviewees, a questionnaire was designed. The questionnaire method is widely used to conduct POE, and it also help identify difficulties in a larger study (Yamamoto, et al. 2003). The subjects of this questionnaire were the general public rather than only people currently taking trains. The objective was to understand the preboarding behavior of experienced passengers in using information signs at Tainan train station.

Experienced train travelers tended to choose information sign A4 to read, which shows the latest train data and timing. Those who rarely traveled by train had no preference in using information; they just wanted to find information they needed from large information.

Buying tickets at the ticket window is the safest way to buy ticket. Travelers can speak to staff and ask questions in person, and there is no need to worry about incorrectly operating the ticket vending machine. People who use Tainan train station often tend to buy ticket from ticket vending machines, which is always faster than buying at ticket window. More passengers buying tickets than from the ticket window expedites the pre-boarding process. However, buying from vending machines can be intimidating for some passengers, especially those who are unfamiliar with the rail system.

Table 3. Experience Level and Pre-boarding Behavior (Questionnaire)

\begin{tabular}{|c|c|c|c|c|}
\hline & Well-familiar & Familiar & Unfamiliar & First time \\
\hline \multicolumn{5}{|l|}{ Experience Level And Use of Signs } \\
\hline Hanging type(Train Schedule Board) & 38 & 77 & 19 & 4 \\
\hline Upper hanging type (Real-time information) & 44 & 101 & 21 & 2 \\
\hline Standing type(Train Schedule Board) & 6 & 22 & 10 & 1 \\
\hline Never used & 0 & 6 & 3 & 1 \\
\hline Others & 1 & 3 & 2 & 0 \\
\hline \multicolumn{5}{|l|}{ Experience Level And Ticket Source } \\
\hline Ticket window & 33 & 83 & 23 & 4 \\
\hline Ticket vending machine & 16 & 25 & 6 & 0 \\
\hline Advance booking ticket & 8 & 17 & 3 & 0 \\
\hline \multicolumn{5}{|l|}{ Experience Level And Use of Waiting Locations } \\
\hline Indoor chairs & 35 & 68 & 19 & 3 \\
\hline Outdoor chairs & 15 & 35 & 10 & 0 \\
\hline In front of gate & 28 & 75 & 19 & 3 \\
\hline Stores & 13 & 43 & 10 & 1 \\
\hline Never wait & 5 & 7 & 6 & 0 \\
\hline Others & 3 & 2 & 1 & 0 \\
\hline \multicolumn{5}{|l|}{ Experience Level And Source of Train Information } \\
\hline Broadcast & 17 & 38 & 14 & 2 \\
\hline Real-time information signs & 25 & 74 & 14 & 3 \\
\hline Watch time & 38 & 81 & 16 & 2 \\
\hline Enter platforms directly & 13 & 25 & 9 & 0 \\
\hline Request information at counter or from other passengers & 5 & 13 & 6 & 1 \\
\hline Other & 3 & 1 & 1 & 1 \\
\hline
\end{tabular}




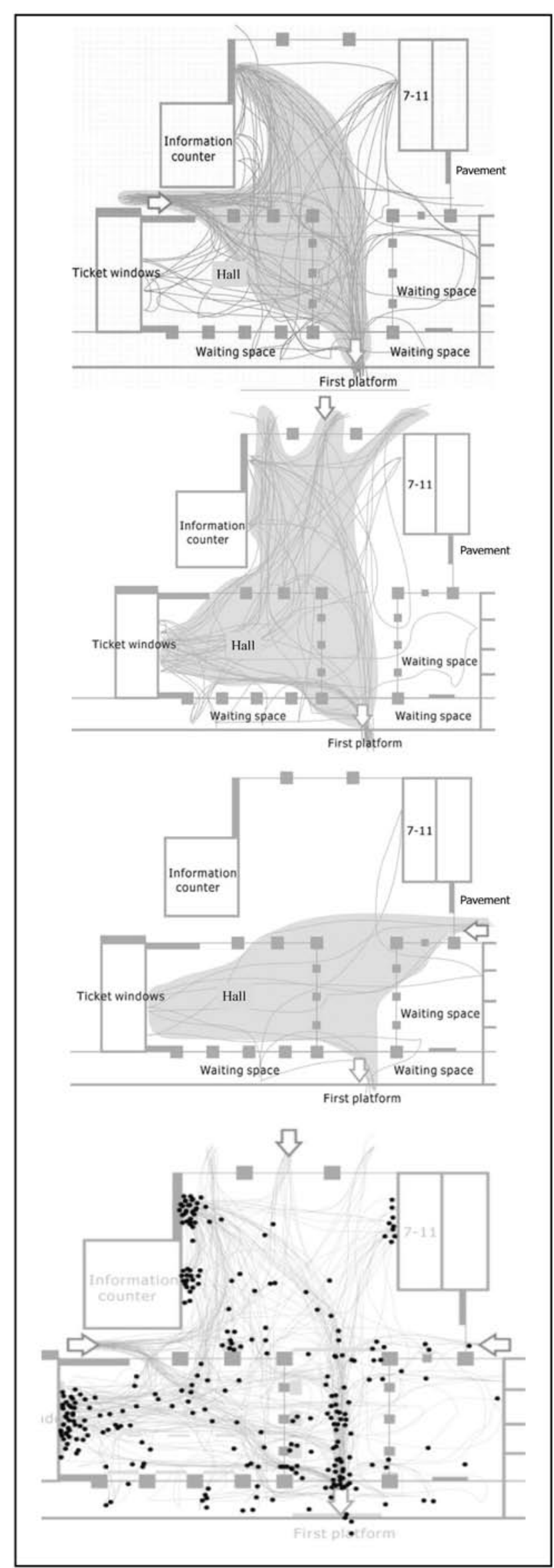

Fig.8. Movement and Stops of Passengers in the Tainan Station Signs
When the station is uncrowded, seats are available for people to rest in any one of the four waiting areas. Since the inner room is air conditioned, people prefer to stay in this area. Experienced travelers prefer to wait in the corridor facing the gate, even though no seats are available there, which is why information sign A4 is provided. Although people should stand before going through the gate, and areas such as corridor are not comfortable for waiting, it is still an effective waiting area for many passengers watching real-time information. Passengers showed preference for using Information sign A4 and listening to train schedule broadcasts to confirm their travel train and platform. Even experienced users of Tainan station ask staff to confirm train schedule. Generally, the habits of experienced travelers should are highly instructive and are also important for sign design.

For example, a real-time information sign installed before gate is clearly useful for travelers. Therefore, the next questions are how users can find them easily and how many should be installed. Additionally, experienced users almost always choose the window to buy ticket. However, no real-time information signs are installed near ticket windows. Therefore, a different design is needed (Table 3.).

\section{Discussion}

Currently, the Tainan train station has numerous information signs. Users intuitively choose the information signs close to the ticket window. Most information signs in the train station are hanging types. Compared with other types, this type does not obstruct movement and saves space. However, numerous advertisement flags on the floor affect people to read information sign A4 that does not have distracting advertisements. This study confirmed that most passengers choose the shortest distance to move to complete their pre-boarding activities. The black dots in Fig.8. represent places where people stop. At these stops, people may buy tickets, gather information, wait, etc. Except ticket buying area, people gather at the area before gates, and notice the content on information sign A4 frequently.

Standing passengers limit the use of station space for others. The observations in this study indicated that standing passengers did not have enough space for two persons to read together. Senior people preferred to buy tickets at the ticket window. They may find it comfortable since they can ask questions face to face. Many of the users in this train station were commuting to work by train. This group of people is experienced in taking trains, so they know how to choose the information signs. The long distance travelers were observed to prefer using the central entrance for entry, but they had to walk longer to buy tickets, or went to platform gate. Hence, how to set up the environment inside and outside the station to make people convenient is a topic that management team should 
consider.

Ticket purchasing and information sign

The survey observed that passenger flow differed on weekdays and holidays and weekends. During holidays and weekends, when passenger traffic is heavy, management team should consider locating information signs strategically. The control of broadcasting and general noise is critical to making passengers comfortable.

From the observation in this survey experienced travelers tended to exhibit the following behaviors.

Enter the train station directly

Read the content of information sign A4 to understand the train schedule

Buy ticket at ticket vending machine

Wait or go to platform directly

The responses of the twelve interviewees indicate that the reason for delays for this group was the excessive information signs and their inability to choose right one. Some information signs provide train schedule and some provide pricing, and different types provide the same information. People spend excessive time finding useful information signs. During the entire "ticket buying and waiting process", searching information and schedule time confirmation were considered time consuming and confusing by respondents. Interviewees with luggage noted the difficulty of negotiating the steps in front of the central entrance. Moreover, central entrance is the main entrance that long journey travelers would use. Hence, providing a non-obstructive environment is one of the urgent topics for planners to consider. The survey also revealed that, although the interviewees had no experience in using the services in Tainan train station, their experience in using trains at other train stations affected their behavior. However, they were often confused by the unique conditions of the Tainan train station. Some of them felt quite anxious.

Questionnaire:

The 200-person survey also indicated that the senior citizens ask for higher quality of service. They prefer to buy tickets in person. More experienced travelers are sensitive to the information signs and advertisements. They know how to find the information from information signs. Observations, interviews and questionnaires in this survey showed that immediate information is very important to all passengers.

Among all train stations in Taiwan, though the Tainan train station is an At-Ground Station, its passenger traffic is the $3^{\text {rd }}$ largest in Taiwan. Management team should consider plans to facilitate passenger flow in this important train facility.

\section{Conclusions}

This study examined the ability of railway passenger behavior to identify key information signs and to enable travelers to buy tickets as quickly as possible. Regarding the design of information signs, those close

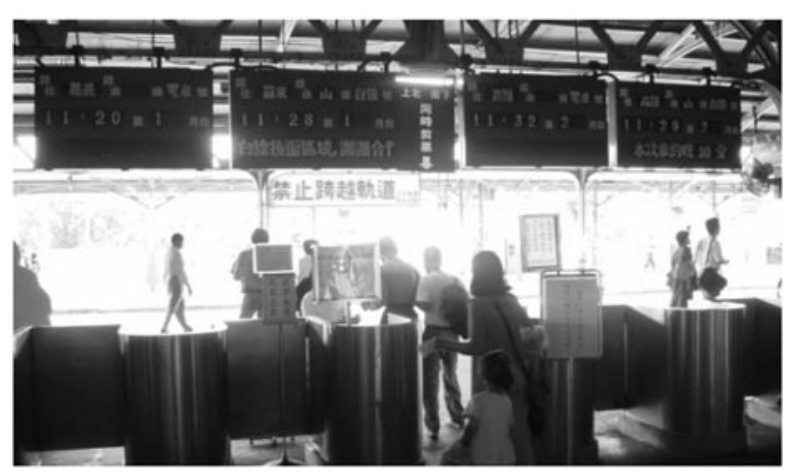

Fig.9. Photograph of Real-time Information Signs (A4)

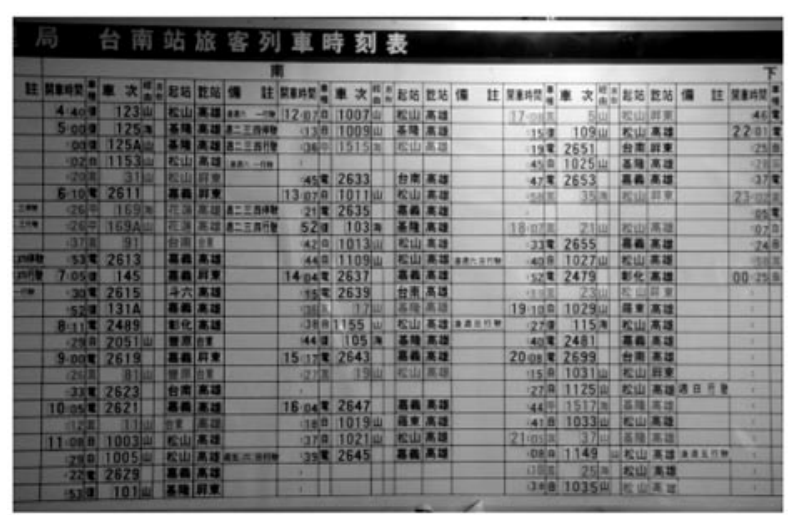

Fig.10. Photograph of Train Schedule Board Installed at Ticket Windows (A1)

to ticket window (A1) can be replaced by information sign A4, which provides immediate information on schedules (Fig.9., Fig. 10.).

This recommendation is supported bt the observation that travelers use information sign A4 most often. Since people can speak to staff about the train schedule when they buy tickets, current complicated schedule information can be replaced. For the same reason, A4 should be placed closer to ticket window. The ticket window and ticket vending machines are close to left and center entrance, which is efficient because the information sign is placed close to these entrances. Many survey respondents complained that the train schedule on the information signs is too complicated and not understandable. Senior citizens generally ignored the signs and asked for help at the ticket windows. Also, only north-south routes can be accessed from the station in Tainan, and the major concern was not the routes but departure and arrival times of trains. Hence, information signs such as A4 provide north-south train schedules and fulfill the requirements of most travelers.

In the Tainan station information signs are placed on the ceiling (ceiling hanging type) or on the walls (hanging type) to save floor space. However, the walls are full of information and advertisements. In train stations, information signs and advertisements are confusing (Zheng, 2007). The resulting confusion requires hurried passengers to spend time finding 
the needed information. To help passengers find necessary information quickly and without confusion, management team can use good graphic designs on walls and corridors as well as pavements and restrict advertisements to limited locations.

Strategically placed seats in waiting areas and accessible train information signs are critical for a well designed train station. Clean and comfortable seats in waiting areas where passengers can easily read or hear train information and relax are essential for a successful public facility. Hence, a well-positioned and uncluttered waiting area is critical. Seats must be provided near information signs giving immediate train information. Passengers buying tickets through ticketing machines are generally highly experienced in using train station. To keep the flow efficient, management team should encourage people to use ticket vending machines, and make necessary changes to help more passengers to feel comfortable using the machines. Additional research is needed to determine why senior citizens prefer to consult ticket agents face to face, and help them use the ticket machines. Information signs have several limitations. For example, if there are many passengers during peak hours, information signs are difficult to read. In such cases, staff should provide temporary support or set up temporary, moveable information signs to guide people. Visual information signs can help people retrieve information themselves; but audio information by broadcast and public announcements is passively distributed. Visual and audio information signs have different active and passive meanings. Broadcasting is acceptable to many people, and announcements in different languages (Mandarin and Taiwanese) are provided. However, in very noisy environments, broadcasting can interfere with normal conversations, especially at peak hours. Audio information signs should be used very carefully. When visual and audio information are placed together, they can significantly improve the flow of pedestrian traffic. Some special behaviors only occur in an historic train station. The Tainan station has design limitations. The content of information signs can be adjusted by careful review and analysis; however, if designers want to allocate the information signs at the right places, they should understand the behavior of travelers, access to immediate information, waiting areas, seats, and traffic flow.

Future studies of train stations should analyze how information signs connect traffic vehicles to their surroundings, and review further improvement for information signs at this station.

\section{References}

1) Mamoru TANAKA, Makoto OHTSUKA, Tanya HIDAKA (2005), The effect of Mixed Environment of Signs for Movement, and Indoor Advertising for Planning of Stations, Journal of Architecture and Planning., AIJ, No 597, pp.23-30.

2) Lee miae (2005), Research Regarding the Design of the General Public Signs at the Pusan station, Bulletin of JJSD, pp.124-125.

3) YAMAMOTO Sari, NISHIKAWA Kiyoshi, HOZUMI Takeshige, TANAKA Sayako (2003), Research on Sign Systems Design for Public Transportation for Users and the Staff, Bulletin of JSSD, pp.90-91.

4) Ivan Chermayeff, Chris Calori (2007), Signage And Wayfinding Design: A Complete Guide to Creating Environmental Graphic Design Systems, p.124.

5) Chao Li (2006), User Preferences, Information Transactions and Location-based services: A Study of Urban Pedestrian Wayfinding, environment and urban systems, vol. 30, n6, pp.726-740.

6) Institute for information design Japan (2003), Information Design Source Book, Graphic-Sha Publishing Co., Ltd.

7) Hu Chia-Hsin (2000), A Study of P.O.E of Space Conditions and Signage Systems in MRT Taipei Main Station-To probe Into the Viewpoints of Users' Wayfinding, National Taipei University of Technology, Taiwan.

8) John Muhlhausen (2002), Signs of the Times Magazine, Wayfinding Is Not Signage- Signage Plays an Important Part of Wayfinding -- but there's more, http://www.signweb.com/ada/cont/ wayfinding0800.html

9) Xue yue-qin, Zeng rui-xian (2000), Design and Manage Rapid Transit System, North District Project Office of the Department of Rapid Transit Systems, Taipei City Government, Taipei, Taiwan.

10) James Grayson Trulove, Connie Sprague (2000) This Way: Signage Design for Public Spaces, Publisher: Rockport Publishers.

11) Zheng Meng-cong(2007), Meng-cong Zheng, Tadao Shimizu, Kiminobu Sato, A Study on information sign system related to users' wayfinding behavior in interchanging above-ground stations. Internationl Association of Societies of Design Research. 